\title{
KEPEMIMPINAN INFORMAL DALAM MEMBERDAYAKAN GABUNGAN KELOMPOK TANI (GAPOKTAN) DI DESA MARGODADI KECAMATAN SEYEGAN KABUPATEN SLEMAN DAERAH ISTIMEWA YOGYAKARTA
}

\section{INFORMAL LEADERSHIP IN EMPOWERING THE GROUP OF FARMERS (GAPOKTAN) IN MARGODADI, SEYEGAN, SLEMAN, SPECIAL REGION YOGYAKARTA}

Oleh:

Fitri Ekasari, Universitas Negeri Yogyakarta

fitriekasari8@gmail.com

\begin{abstract}
Abstrak
Penelitian ini bertujuan untuk mendeskripsikan: (1) Peran kepemimpinan informal dalam memberdayakan Gabungan Kelompok Tani (GAPOKTAN) (2) Proses kepemimpinan informal dalam memberdayakan Gabungan Kelompok Tani (GAPOKTAN) (3) Kendala yang dihadapi kepemimpinan informal dalam memberdayakan Gabungan Kelompok Tani (GAPOKTAN). Hasil penelitian menunjukkan bahwa : 1) Peran kepemimpinan informal dalam memberdayakan Gabungan Kelompok Tani meliputi koordinator, fasilitator, pengawas, konsultan, informan, partisipan dan evaluator. 2) Proses kepemimpinan informal dalam memberdayakan Gabungan Kelompok Tani bersifat terbuka yaitu mengutamakan musyawarah dan kepentingan bersama melalui pertemuan rutin, terjun langsung ke lapangan dan regenerasi dengan gaya kepemimpinan demokratis. 3) Kendala yang dihadapi pemimpin informal dalam memberdayakan Gabungan Kelompok Tani meliputi faktor usia, pola pikir petani sulit berubah dalam menerima perubahan, perbedaan pendapat dan kurangnya minat generasi muda.
\end{abstract}

Kata Kunci: kepemimpinan informal, pemberdayaan,GAPOKTAN

\begin{abstract}
The purpose of this research to describe: 1) The role of informal leadership in empowering the Joint Farmer Group (GAPOKTAN) 2) Informal leadership process in empowering the Growing Farmer Group (GAPOKTAN) 3) The constraints faced by informal leadership in empowering the Agricultural Groups (GAPOKTAN). The research has shown that: 1) The role of informal leadership in empowering the Combined Farmer Group includes coordinators, facilitators, supervisors, consultants, informants, participants and evaluator. 2) The informal leadership process in empowering the Joint Farmer Group is open to prioritizing deliberations and common interests through regular meetings, direct entry into the field and regeneration with a democratic leadership style. 3) The obstacles faced by informal leaders in empowering the Combined Farmer Group include age factors, farmers' mindset is difficult to change in accepting change, disagreements and lack of interest from young people.
\end{abstract}

Keywords: informal leadership, empowerment, GAPOKTAN

\section{PENDAHULUAN}

Organisasi merupakan wadah atau tempat bagi kelompok orang yang mempunyai kepentingan sama ke dalam aktivitas atau kegiatan dengan sistem kerjasama untuk mencapai visi dan tujuan bersama, baik formal maupun informal. Organisasi yang mencangkup berbagai kelompok orang didalamnya adalah Gabungan Kelompok Tani (GAPOKTAN). Menurut Peraturan Menteri Nomor 273/Kpts/OT.160/4/2007 tentang Pedoman
Penumbuhan dan Tingkat Kelompok Tani dan Gabungan Kelompok Tani (GAPOKTAN), yang dimaksud dengan kelompok tani adalah kumpulan petani/peternak/pekebun yang dibentuk atas dasar kesamaan kepentingan, kesamaan kondisi lingkungan (sosial, ekonomi, sumberdaya) dan keakraban untuk meningkatkan dan mengembangkan usahanya. Gabungan Kelompok Tani (GAPOKTAN) terbentuk karena adanya kesamaan kebutuhan dan kepentingan yang dirasakan oleh masing-masing kelompok. 


\section{Diklus: Jurnal Pendidikan Luar Sekolah, 2(1), Maret 2018 - 25 Fitri Ekasari}

Menurut Kementrian Pertanian dalam Rencana Strategi Kementrian Pertanian Tahun 2015-2019, petani merupakan pelaku utama dalam pembangunan pertanian, sudah seharusnya mendapatkan hak yang sepadan dengan curahan waktu, tenaga dan pikiran yang telah dicurahkan untuk bekerja di bidang pertanian. Program dan kegiatan dilaksanakan dalam upaya meningkatkan kesejahteraan petani meliputi pemberdayaan, penyuluhan, pendampingan, penjaminan usaha, perlindungan harga gabah, kebijakan proteksi dan promosi.

Menurut data statistik Badan Penyuluhan Dan Pengembangan Sumber Daya Manusia Pertanian potensi GAPOKTAN di wilayah Kabupaten Yogyakarta dari tahun 2012 sampai 2013 tidak mengalami peningkatan. Dilihat dari jumlah anggota tidak ada peningkatan, namun dari segi kelompok tani mengalami peningkatan jumlah sebesar 1.271. Pada tahun 2012 sejumlah 386, sedangkan kelompok tani sejumlah 5.235 dengan jumlah anggota 224.899 orang. Pada tahun 2013 sejumlah 386, sedangkan kelompok tani sejumlah 6.506 dengan jumlah anggota 224.899 orang. Gabungan Kelompok Tani (GAPOKTAN) di Desa Margodadi Kecamatan Seyegan Kabupaten Sleman Daerah Istimewa Yogyakarta yaitu Dadi Makmur dengan jumlah kelompok 38 dan anggota 1.171 orang.

Berdasarkan data yang diperoleh dari BPS (Badan Pusat Statistik), jumlah petani pada tahun 2003 sampai 2013 mengalami penurunan. Dari 31,17 juta jumlah petani, menurun hingga 26,13 juta jumlah petani. Penurunan jumlah petani sekitar 5 juta selama sepuluh tahun, atau $1,75 \%$ per tahun. Hal tersebut mempengaruhi sektor ekomoni. Karena produk pertanian yang semakin langka dan mahal. Semakin turun minat masyarakat dan pengalih fungsi lahan dari lahan pertanian menjadi nonpertanian seperti toko dan supermarket membuat sektor pertanian semakin menurun. Hal tersebut sejalan seperti yang dikemukakan oleh Sigit Harjono SP MP, Kasi Pengelolaan Lahan Air, Bidang Tanaman Pangan Dinas Pertanian DIY bahwa "Sebaran alih fungsi lahan sebesar $2.942 \mathrm{Ha}$ meliputi Sleman 1.496 Ha, Bantul 1.085 Ha, Kota Yogya 62 Ha, Gunungkidul $235 \mathrm{Ha}$ dan Kulonprogo $520 \mathrm{Ha}$. Alih fungsi lahan pertanian juga mempercepat proses marjinalisasi usaha tani sehingga menggrogoti daya saing produk pertanian domestik" (Kedaulatan Rakyat, 25 Februari 2017). Sedangkan Sensus penduduk oleh BPS (2016) melaporkan bahwa penduduk Indonesia berjumlah 258 juta jiwa dan memerlukan kebutuhan akan pangan. Hal ini mendorong pembangunan pertanian untuk memenuhi kebutuhan penduduk. Sektor pertanian diharapkan menjalankan perannya secara optimal karena sektor ini telah menjadi tumpuan bagi masyarakat Indonesia, khususnya bagi para petani (Putri, 2013:1).

Kasus perkembangan PUPM melalui kegiatan Toko Tani Indonesia (TTI) tingkat gapoktan dan petani tahun 2017. Pada interval 35 hari, volume beras tingkat gapoktan $4.450 \mathrm{~kg}$, harga beras tingkat gapoktan Rp7.661,00 volume beli gabah dari petani $9.467 \mathrm{~kg}$ dan harga beli gabah dari petani Rp4.795,00 . Pada interval 28 hari, volume beras tingkat gapoktan $2.553 \mathrm{~kg}$, harga beras tingkat gapoktan Rp7.575,00 volume beli gabah dari petani $5.459 \mathrm{~kg}$ dan harga beli gabah dari petani Rp4.758,00. Pada interval 21 hari, volume beras tingkat gapoktan $2.536 \mathrm{~kg}$, harga beras tingkat gapoktan Rp7.640,00 volume beli gabah dari petani $5.685 \mathrm{~kg}$ dan harga beli gabah dari petani Rp4.805,00. Pada interval 14 hari, volume beras tingkat gapoktan $2.671 \mathrm{~kg}$, harga beras tingkat gapoktan Rp7.442,00 volume beli gabah dari petani $6.676 \mathrm{~kg}$ dan harga beli 


\section{Diklus: Jurnal Pendidikan Luar Sekolah, 2(1), Maret 2018 - 26 \\ Fitri Ekasari}

gabah dari petani Rp4.819,00 Sedangkan pada minggu ke 3 bulan februari 2017, volume beras tingkat gapoktan $2.793 \mathrm{~kg}$, harga beras tingkat gapoktan Rp7.561,00 volume beli gabah dari petani $6.749 \mathrm{~kg}$ dan harga beli gabah dari petani Rp4.741,00 (tti.pertanian.go.id). Kasus ini menggambarkan bahwa terjadi kenaikan volume beli gabah dari petani, namun penurunan harga beli gabah dari petani. Volume beli gabah dari petani mengalami kenaikan yang sangat signifikan dari $4.795 \mathrm{~kg}$ ke $6749 \mathrm{~kg}$. Sedangkan harga beli gabah dari petani mengalami penurunan signifikan pada minggu ke 3 bulan februari 2017, yaitu dari Rp4.819,00 untuk 6.676 kg ke Rp4.741,00 untuk $6.749 \mathrm{~kg}$. Untuk volume beras dan harga beli beras tingkat gapoktan, mengalami kenaikan. Pada interval 14 ke minggu ke 3 bulan februari 2017. Volume beras $2.671 \mathrm{~kg} \quad \mathrm{ke} 2.739 \mathrm{~kg}$ dan Rp7.442,00 ke Rp7.561,00.

Berdasarkan permasalahan tersebut, perlu kiranya perhatian dan penanganan khususnya pemberdayaan Gabungan Kelompok Tani (GAPOKTAN). Lemahnya pengetahuan petani akan pengelolaan hasil panen, informasi pasar, akses pasar, pemodalan dalam rantai distribusi pertanian membuat petani semakin lemah. Kondisi tersebut membuat petani beralih profesi dan mengubah lahan pertanian menjadi gedung usaha yang lebih menguntungkan. Ketersediaan dan pasokan beras akan berakibat terhadap terjadinya gejolak harga di pasar, dan berdampak Pada stabilitas ekonomi, sosial dan keamanan negara (Ariaty, 2016).

Salah satu kelemahan yang mendasar adalah kegagalan pengembangan kelompok, karena tidak dilakukan melalui proses sosial yang matang (Pujiharto, 2010). Kepercayaan, komitmen dan motivasi petani dalam melihat peluang dalam pertanian semakin lemah. Peluang mempengaruhi tingkat komitmen bawahan yang mengalami kemajuan dalam karirnya secara keseluruhan akan mempunyai persepsi positif pada organisasi (Safaria, 2004). Akibat persepsi positif ini petani akan termotivasi untuk mencurahkan tenaga dan waktunya secara maksimal untuk memberikan kontribusi bagi kemajuan organisasi. Didalam komitmen terhadap organisasi terdapat loyalitas, penerimaan dan keyakinan akan tujuan organisasi secara keseluruhan.

Pemberdayaan gabungan kelompok tani merupakan sebuah kegiatan yang melibatkan partisipasi dan kepemimpinan. Kepemimpinan sangat besar pengaruhnya terhadap upaya pencapaian tujuan organisasi (Wuradji. 2009). Pemimpin yang dipilih berdasarkan kesepakatan bersama berdasarkan psikologis, pengalaman, ilmu pengetahuan dan keterampilan yang diakui oleh anggota organisasi yaitu petani. Pimpinan informal (tokoh masyarakat, pemuka agama, adat, LSM, guru, bisnis, dan lain-lain), artinya seseorang yang ditunjuk memimpin secara tidak formal, karena memiliki kualitas unggul, dia mencapai kedudukan sebagai seorang yang mampu memengaruhi kondisi psikis dan perilaku suatu kelompok/komunitas tertentu (Rivai, 2013).

Kepemimpinan informal memiliki peranan sosial dalam mengambil tanggung jawab dan keefektifan serta produktivitas organisasi di tengah masyarakat. Peranan sosialnya dalam memberikan pengaruh berupa sugesti, larangan, dan dukungan kepada masyarakat luas untuk menggerakkan atau berbuat sesuatu (Kartono, 2011).

Sehingga dalam kepemimpinan tidak hanya mengarah kepada individual namun keseluruhan kelompok. Hal tersebut mampu mendengarkan dan memperhatikan pendapat, kebutuhan, perasaan bahkan konflik yang ada dilapangan, serta mampu berinteraksi dan berada di tengah-tengah kelompok untuk memandang kelompok sebagai keseluruhan 


\section{Diklus: Jurnal Pendidikan Luar Sekolah, 2(1), Maret 2018 - 27 \\ Fitri Ekasari}

kolektivitas atau sistem sosial. Kepemimpinan dalam Gabungan Kelompok Tani (GAPOKTAN) mengarah pada kepemimpinan informal. Hal tersebut dikarenakan Gabungan Kelompok Tani (GAPOKTAN) meliputi kelompok tani terdiri dari karakteristik petani-petani yang memiliki keahlian khusus dalam situasi khusus yaitu dalam bidang pertanian.

Penjelasan tersebut menarik peneliti untuk mengamati mengenai bagaimana kepemimpinan informal yang ada di Desa Margodadi Kecamatan Seyegan Kabupaten Sleman Daerah Istimewa Yogyakarta. Peneliti juga ingin mengetahui bagaimana kepemimpinan informal dalam memberdayakan Gabungan Kelompok Tani (GAPOKTAN) di Desa Margodadi Kecamatan Seyegan Kabupaten Sleman Daerah Istimewa Yogyakarta dengan mengetengahkan judul "Kepemimpinan Informal dalam Memberdayakan Gabungan Kelompok Tani (GAPOKTAN) di Desa Margodadi Kecamatan Seyegan Kabupaten Sleman Daerah Istimewa Yogyakarta".

\section{METODE PENELITIAN}

\section{Jenis Penelitian}

Pendekatan penelitian merupakan keseluruhan cara atau kegiatan yang dilakukan oleh peneliti dalam melaksanakan penelitian dimulai dari merumuskan masalah sampai dengan penarikan suatu kesimpulan. Pendekatan dalam penelitian ini menggunakan pendekatan kualitatif. Penelitian kualitatif adalah penelitian yang bermaksud untuk memahami fenomena tentang apa yang dialami oleh subyek penelitian, misalnya perilaku, persepsi, motivasi, tindakan, dan lain-lain, secara holistik dan dengan cara deskripsi dalam bentuk kata-kata dan bahasa, pada suatu konteks khusus yang alamiah dan dengan memanfaatkan berbagai metode alamiah (Moleong, 2012:6)

\section{Setting dan Waktu Penelitian}

Lokasi penelitian yaitu Gabungan Kelompok Tani (GAPOKTAN) di Desa Margodadi Kecamatan Seyegan Kabupaten Sleman Daerah Istimewa Yogyakarta. Penelitian ini dilaksanakan selama tiga bulan, yaitu dilaksanakan pada 5 Mei - 11 Agustus 2017.

\section{Subyek Penelitian}

Penentuan subyek penelitian ini menggunakan teknik purposive sampling. Teknik purposive sampling menetukan subyek penelitian sesuai dengan tujuan penelitian. Purposive sampling merupakan teknik pengambilan sampel sumber data dengan menggunakan pertimbangan tertentu (Sugiyono, 2012: 300). Pemilihan subyek dalam penelitian ini mempertimbangkan keterlibatan informan dalam program yang dilaksanakan Gabungan Kelompok Tani (GAPOKTAN).

Subyek dalam penelitian ini meliputi pemimpin informal, ketua Gabungan Kelompok Tani (GAPOKTAN).dan petani.

\section{Data, Intrumen, dan Teknik Pengumpulan Data}

Pengumpulan data pada penelitian ini menggunakan teknik wawancara, observasi serta dokumentasi berupa pengumpulan dokumen administrasi, foto, maupun bentuk lainnya yang sesuai dengan kebutuhan. Instrumen utama dalam penelitian ini ialah peneliti sendiri. Dibantu dengan adanya pedoman observasi, pedoman wawancara, serta pedoman dokumentasi untuk pengumpulan data. 


\section{Diklus: Jurnal Pendidikan Luar Sekolah, 2(1), Maret 2018 - 28 \\ Fitri Ekasari}

\section{Teknik Analisis Data}

Analisis data menggunakan teknik analisis data model interaktif yang terdiri dari pengumpulan data, reduksi data, penyajian data, dan penarikan kesimpulan \& verifikasi.

\section{Pengumpulan Data}

Pengumpulan data dengan beberapa cara yaitu observasi, wawancara, intisari dokumentasi, pita rekaman dan diproses melalui pencatatan, pengetikan, serta penyuntingan. Tetapi analisis tetap menggunakan kata-kata yang disusun ke dalam teks yang digeneralisasikan.

\section{Reduksi Data}

Mereduksi data berarti merangkum, memilih hal-hal yang pokok, memfokuskan pada hal-hal yang penting, dicari tema dan polanya dan membuang yang tidak perlu.

\section{Penyajian Data}

Penyajian data tersusun dari sekumpulan informasi yang memeberi kemungkinan adanya penarikan kesimpulan dan pengambilan tindakan. Dalam penelitian ini, peneliti menyajikan data yang telah direduksi secara deskriptif dalam uraian naratif.

\section{Penarikan Kesimpulan \& Verifikasi}

Penarikan kesimpulan merupakan tahap dimana peneliti memaparkan temuan baru yang dapat memberikan jawaban atas rumusan masalah diawal. Kesimpulan diverifikasi selama penelitian berlangsung dan melakukan validasi data didukung oleh bukti yang valid, konsisten dan kredibel.

\section{Keabsahan Data}

Dalam penelitian ini, pemeriksaan keabsahan data dilakukan dengan triangulasi sumber dan teknik. Triangulasi sumber dilakukan dengan cara mengecek data yang telah diperoleh melalui beberapa sumber yaitu pemimpin informal, ketua gapoktan dan petani. Triangulasi sumber dilakukan dengan cara mengecek data kepada sumber yang sama namun dengan teknik yang berbeda, yaitu wawancara, observasi dan dokumentasi.

HASIL PENELITIAN DAN PEMBAHASAN

Peran Kepemimpinan Informal dalam Memberdayakan Gabungan Kelompok Tani (GAPOKTAN)

Dalam penelitian ini, wujud peran kepemimpinan informal dalam memberdayakan Gabungan Kelompok Tani (GAPOKTAN) yaitu keterlibatan pemimpin informal, program yang diikuti pemimpin informal, peran pemimpin informal dalam program, fungsi pemimpin informal dalam kelompok tani dan prinsip kepemimpinan informal dalam kelompok tani. Hasil penelitian mengenai peran kepemimpinan informal dalam memberdayakan Gabungan Kelompok Tani (GAPOKTAN) yaitu sebagai berikut.

\section{a. Keterlibatan Pemimpin Informal}

Keterlibatan pemimpin informal sesuai dengan tinjauan kepemimpinan informal. Pimpinan informal (tokoh masyarakat, pemuka agama, adat, LSM, guru, bisnis, dan lain-lain), artinya seseorang yang ditunjuk memimpin secara tidak formal, karena memiliki kualitas unggul, dia mencapai kedudukan sebagai seorang yang mampu memengaruhi kondisi psikis dan perilaku suatu kelompok/komunitas tertentu (Rivai, 2013: 3-4). 


\section{Diklus: Jurnal Pendidikan Luar Sekolah, 2(1), Maret 2018 - 29 Fitri Ekasari}

Pemimpin informal ialah orang yang tidak mendapatkan peningkatan formal sebagai pemimpin, namun karena ia memiliki sejumlah kualitas unggul, dia mencapai kedudukan sebagai orang yang mampu mempengaruhi kondisi psikis dan perilaku suatu kelompok atau masyarakat Kartono (2011: 10)

Pemimpin informal hadir dan terlibat dalam kegiatan baik yang diadakan oleh pemerintah atau GAPOKTAN, mulai dari penyelesaian permasalahan petani dalam pertanian, perencanaan program, pelaksanaan program, evaluasi program dan pemberdayaan pemuda. Kehadiran pemimpin informal yaitu sekitar 2 sampai 6 orang meliputi guru, tentara, bisnis dan tokoh masyarakat. Hal tersebut dapat dilihat dari pekerjaan pemimpin informal dan daftar kehadiran pemimpin informal dalam kegiatan gapoktan.

\section{b. Program yang Diikuti Pemimpin Informal}

Program yang ikuti pemimpin informal meliputi Program yang diikuti meliputi mina padi dan pertemuan rutin. Kegiatan dalam program mina padi meliputi penyediaan pupuk, penyediaan benih ikan, penyediaan pakan, penyuluhan, pemasaran, dan ronda sawah. Selain itu, pemimpin informal terlibat dalam kegiatan pelatihan dan simpan pinjam. Program tersebut diikuti oleh pemimpin informal di Desa Margodadi Kecamatan Seyegan Kabupaten Sleman Daerah Istimewa Yogyakarta merupakan wujud dari peran pemimpin informal untuk memberdayakan gapoktan dalam mempengaruhi kondisi dan perilaku gapoktan.

Pemimpin informal ialah orang yang tidak mendapatkan peningkatan formal sebagai pemimpin, namun karena ia memiliki sejumlah kualitas unggul, dia mencapai kedudukan sebagai orang yang mampu mempengaruhi kondisi psikis dan perilaku suatu kelompok atau masyarakat
Kartono (2011: 10). Kepemimpinan informal menjadi kunci guna keberhasilan program atau proyek kegiatan desa. Pemimpin informal meningkatkan kondisi dan perilaku petani berdasarkan potensi, kondisi dan kekhususan masyarakatnya. Pemimpin informal muncul dalam berbagai kegiatan, baik kegiatan resmi pemerintah maupun kegiatan swadaya masyarakat.

\section{c. Peran Pemimpin Informal dalam Program}

Peran pemimpin informal dalam program mengacu pada fungsi kepemimpinan. Fungsi dalam kelompok atau organisasi adalah pemimpin organisasi bertugas mengorganisasikan, mengkoordinasikan dan mengendalikan, pemimpin organisasi harus memiliki kemampuan merencanakan kegiatan yang akan berdampak positif bagi kemajuan organisasi, serta pemimpin organisasi berfungsi sebagai pengawas dan evaluator (Saebani, 2014: 62-63). Fungsi kepemimpinan dalam pekerjaan dan hubungan interpersonal. Fungsi dalam pekerjaan diantaranya memulai (initianting), mengatur (regulating), memberitahu (informing), mendukung (supporting), menilai (evaluating) dan menyimpulkan (summarizing) (Malahayati, 2010: 22-23).

Peran pemimpin informal di Desa Margodadi Kecamatan Seyegan Kabupaten Sleman Daerah Istimewa Yogyakarta dalam program yaitu koordinator, fasilitator, pengawas, konsultan, informan dan partisipan. Pemimpin informal mengkoordinasi dalam rancangan program berdasarkan permasalahan, sosialisasi program pada petani, perencanaan program, pelaksanaan program, evaluasi program dan keberlanjutan program. Peran pemimpin informal dalam program berupa fasilitator setiap kegiatan yang akan dilaksanakan baik dalam program pemerintah, 


\section{Diklus: Jurnal Pendidikan Luar Sekolah, 2(1), Maret 2018 - 30 \\ Fitri Ekasari}

gapoktan maupun internal petani seperti simpan pinjam. Peran pemimpin informal sebagai pengawas, pemimpin informal mengawasi pertanian petani, perikanan dan permasalahan petani serta program. Dalam peran pemimpin informal sebagai konsultasi, pemimpin informal memberikan informasi kepada petani terkait dengan kondisi petani, permasalahan maupun program yang sedang dilaksanakan atau sudah dilaksanakan. Sedangkan peran pemimpin informal sebagai partisipan, dalam setiap kegiatan yang dilaksanakan pemimpin informal berpartisipasi langsung, mulai dari pelaksanaan kegiatan sampai panen.

\section{d. Fungsi Kepemimpinan Informal}

Fungsi kepemimpinan informal mengacu pada fungsi kepemimpinan. Secara operasional, fungsi kepemimpinan dibedakan menjadi lima pokok (Rivai, 2013: 34) yaitu instruksi, konsultasi, partisipasi, delegasi dan pengendalian. Faktor instruksi, pemimpin sebagai komunikator agar keputusan dapat dilaksanakan secara efektif. Faktor konsultasi, pemimpin menetapkan keputusan dengan mempertimbangkan, berdiskusi dengan orang yang dipimpin, dan menetapkan keputusan. Setelah menetapkan keputusan, pemimpin berdiskusi dengan orang yang dipimpin dalam pelaksanaan, untuk memperoleh masukan berupa umpan balik (feedback) untuk memperbaiki dan menyempurnakan keputusan-keputusan yang telah ditetapkan dan dilaksanakan. sehingga kepemimpinan berlangsung efektif. Fungsi partisipasi yaitu keikutsertaan pemimpin informal dalam pengambilan keputusan sampai evaluasi. Sedangkan, fungsi pengendalian dapat diwujudkan melalui kegiatan bimbingan, pengarahan, koordinasi dan pengawasan (Rivai, 2013: 35).
Fungsi kepemimpinan informal di Desa Margodadi Kecamatan Seyegan Kabupaten Sleman Daerah Istimewa Yogyakarta yaitu sebagai informan, partisipasi dan pengendali (kegiatan bimbingan, pengarahan, koordinasi dan pengawasan).

\section{e. Prinsip Kepemimpinan Informal}

Prinsip kepemimpinan informal mengacu pada prinsip kepemimpinan. Prinsip-prinsip kepemimpinan yaitu melayani, membuat keputusan, keteladanan, bertanggungjawab, berkerjasama dan menciptakan perubahan (Tambunan, 2015: 67). Dalam menciptakan kesejahteraan petani dan memajukkan petani di Desa Margodadi Kecamatan Seyegan Kabupaten Sleman Daerah Istimewa Yogyakarta, pemimpin informal menerapkan prinsip melayani yaitu pertama, mendengarkan yaitu pemimpin informal berkomunikasi dengan mendengarkan dulu. Kedua, empati artinya pemimpin informal memahami apa yang dipikirkan dan dirasakan petani. Ketiga, perhatian artinya pemimpin melayani dimana membuat mereka cepat beradaptasi dan peka terhadap lingkungan. Keempat, persuasi artinya komunikasi antara pemimpin dan petani yang jelas untuk meyakinkan orang lain berubah. Kelima, konseptualitas artinya pemimpin membuat petani memiliki kemampuan untuk menjadi orang yang berpandangan jauh ke depan dan memiliki pemahaman yang jelas akan tujuan dan arahan. Keenam, peramalan artinya pemimpin informal memiliki kemampuan untuk mengetahui pandangan kedepan. Ketujuh, tugas untuk mengurus, artinya pemimpin memiliki tanggungjawab. Kedelapan, pemimpin informal memiliki komitmen untuk membantu setiap orang didalam organisasi agar bisa maju. Kesembilan, membangun dan memperkuat organisasi. 


\section{Diklus: Jurnal Pendidikan Luar Sekolah, 2(1), Maret 2018 - 31 Fitri Ekasari}

Hal tersebut sesuai dengan prinsip kepemimpinan informal di Desa Margodadi Kecamatan Seyegan Kabupaten Sleman Daerah Istimewa Yogyakarta yaitu mensejahterakan petani, memajukan petani dan meningkatkan minat generasi muda. Ide-ide, perubahan, kerjasama dan tanggungjawab dalam mencapai tujuan bersama, baik personal, antar perorangan, manajerial dan organisasional.

Dalam mensejahterakan dan memajukan petani di Desa Margodadi Kecamatan Seyegan Kabupaten Sleman Daerah Istimewa Yogyakarta, pemimpin informal bekerjasama dengan baik dengan pihak terkait seperti anggota gapoktan dan pemerintah. Selain itu, pemimpin informal menciptakan perubahan dengan cara pemimpin harus mempunyai ide baru, inovatif dan kreatifitas. Sehingga tercipta suatu perubahan baik di organisasi, orang-orang yang dipimpin atau produk.

Proses Kepemimpinan Informal dalam Memberdayakan Gabungan Kelompok Tani (GAPOKTAN)

a. Pendekatan Kepemimpinan Informal dalam Kegiatan GAPOKTAN

Pendekatan kepemimpinan informal dalam kegiatan gapoktan mengacu pada teori kepemimpinan. Teori yang sesuai dengan pendekatan kepemimpinan infornal di Desa Margodadi Kecamatan Seyegan Kabupaten Sleman Daerah Istimewa Yogyakarta yaitu teori situasional hersey dan blatcchard. Teori kepemimpinan situasional hersey dan blatcchard berfokus pada karakteristik bawahan sebagai kunci pokok situasi yang menentukan kefektifan perilaku seorang pemimpin. Bawahan memiliki tingkat kesiapan dan kematangan yang berbeda-beda sehingga pemimpin harus mampu menyesuaikan gaya kepemimpinannya agar sesuai dengan situasi kesiapan dan kematangan bawahan (Safaria, 2004: 70-71).

Pendekatan pemimpin informal di Desa Margodadi Kecamatan Seyegan Kabupaten Sleman Daerah Istimewa Yogyakarta menekankan pada situasi kesiapan dan kematangan bawahan dengan pertemuan rutin, terjun langsung ke lapangan dan regenerasi.

Pertemuan rutin dilaksanakan satu bulan sekali dirumah pemimpin informal atau petani. dalam pertemuan rutin, pemimpin informal dan petani musyawarah terkait dengan program yang akan dilaksanakan, perkembangan program yang sudah berjalan dan permasalahan yang dialami petani dalam pertanian. Pendekatan pemimpin informal berupa turun ke lapangan yaitu pengecekkan program dan pertanian petani dengan berbincang-bincang dengan petani ditepi sawah. Sedangkan regenerasi yaitu pendekatan pemimpin informal dalam meningkatkan minat generasi muda di Desa Margodadi Kecamatan Seyegan Kabupaten Sleman Daerah Istimewa Yogyakarta melalui hidroponik, perikanan dan pemasaran.

\section{b. Penyampaian ide atau gagasan pemimpin informal}

Penyampaian ide atau gagasan pemimpin informal mengacu pada gaya kepemimpinan yaitu gaya kepemimpinan demokratis. Gaya kepemimpinan demokratis memiliki ciri-ciri yaitu (Saebani, 2014: 129-130)
a) Bawahan diberi kesempatan untuk mengembangkan kreativitas
b) Bersifat terbuka
c) Mengutamakan musyawarah dan kepentingan bersama
d) Mengambil keputusan sesuai dengan tujuan organisasi




\section{Diklus: Jurnal Pendidikan Luar Sekolah, 2(1), Maret 2018 - 32 \\ Fitri Ekasari}

e) Berpartisipasi aktif dalam kegiatan organisasi

f) Mengembangkan regenerasi kepemimpinan

g) Perluasan kaderisasi agar bawahan lebih maju dan menjadi pemimpin masa depan

h) Memandang semua masalah dapat dipecahkan dengan usaha bersama.

Gaya kepemimpinan demokratis dalam penyampaian ide atau gagasan pemimpin informal di Desa Margodadi Kecamatan Seyegan Kabupaten Sleman Daerah Istimewa Yogyakarta bersifat terbuka yaitu mengutamakan musyawarah dan kepentingan bersama. Petani bebas mengemukakan pendapat terkait dengan permasalahan di sawah maupun program. Dalam proses musyawarah, pemimpin informal menyampaikan ide dan pendapatnya mulai dari program yang akan atau sudah dilaksanakan, perkembangan pertanian saat ini, maupun menanggapi pendapat petani terkait dengan permasalahan.

Kendala yang Dihadapi Kepemimpinan Informal dalam Memberdayakan Gabungan Kelompok Tani (GAPOKTAN)

\section{a. Kendala yang Dihadapi Pemimpin Informal}

Kendala yang dihadapi pemimpin informal mengacu pada kendala kepemimpinan. Saebani (2014: 159) menyatakan bahawa kendala kepemimpinan meliputi kendala dalam diri individu, antar pribadi dan dalam organisasi. berdasarkan pernyataan tersebut, penelitian ini fokus pada kendala dalam diri, antar personal dan organisasi.

Kendala dalam diri individu, bila individu diharapkan untuk melakukan lebih dari kemampuannya (Fahmi, 2012: 268). Kendala dalam diri individu yaitu tidak mau mencoba mengatasi keterbatasan dan memenuhi kebutuhannya sehingga dapat berkembang. Kendala antarpribadi terjadi jika dua orang atau lebih berinteraksi satu sama lain dalam melaksanakan pekerjaan (Thoha, 2015:106). Kendala yang dihadapi seperti : dua orang yang memiliki pandangan-pandangan yang tidak bisa disatukan, orang yang tidak bisa bertoleransi dan orang yang menutup diri. Setiap pribadi terdapat beberapa tujuan yang mungkin sama, searah dan saling mendukung, tetapi bisa sebaliknya, tidak sama dan searah sehingga terjadi perbedaan kepentingan (Julitriarsa, 2001: 89).

Sedangkan, kendala dalam organisasi, kendala ini melihat dalam hubungan dengan tatanan organisasi yang bersendikan orang-orang yang bekerja sama untuk mencapai suatu tujuan bersama (Thoha, 2015: 110). Pemimpin harus senantiasa memberikan penjelasan dan keteranganketerangan mengenai hal-hal yang seharusnya diketahui anggota (Julitriarsa, 2001: 95). Kendala dalam organisasi salah satunya memperbaiki dan mengembangkan komunikasi. Kendala yang dihadapi seperti: timbulnya persepsi yang berbeda, suatu situasi yang tidak menunjukkan keseimbangan tujuan-tujuan yang dicapai, pemimpin kurang mempunyai otoritas tetapi mempunyai tanggungjawab yang besar, timbulnya proses alokasi sumber-sumber yang tidak tercapai dan kendala fungsional diantara berbagai bagian organisasi yang mempunyai fungsi- fungsi tertentu.

Kendala yang dihadapi pemimpin informal dalam memberdayakan gapoktan di Desa Margodadi Kecamatan Seyegan Kabupaten Sleman Daerah Istimewa Yogyakarta yaitu faktor usia petani yang sudah lanjut, pola pikir petani yang sulit berubah membuat petani kurang mampu menerima perubahan yang diberikan pemimpin informal sehingga membuat perbedaaan pandangan, persepsi yang berbeda, dan tujuan yang tidak dicapai. Perbedaan harga antara harga petani dengan harga dipasar, panjangnya rantai distribusi 


\section{Diklus: Jurnal Pendidikan Luar Sekolah, 2(1), Maret 2018 - 33 Fitri Ekasari}

dan kurangnya minat generasi muda dalam kelompok menjadi kendala pemimpin informal dalam mensejahterakan dan memajukan pertanian di Desa Margodadi Kecamatan Seyegan Kabupaten Sleman Daerah Istimewa Yogyakarta.

\section{b. Cara Pemimpin Informal dalam}

\section{Menyelesaikan permasalahan}

Cara pemimpin informal dalam menyelesaikan permasalahan dalam memberdayakan gapoktan di Desa Margodadi Kecamatan Seyegan Kabupaten Sleman Daerah Istimewa Yogyakarta mengacu pada teori kepemimpinan dan gaya kepemimpinan yaitu teori transformasional dan gaya kepemimpinan coaching. Teori kepemimpinan transformasional berusaha mengembangkan sistem yang sedang berlangsung dengan mengemukakan visi yang mendorong berkembangnya masyarakat baru (Wirawan, 2014: 138). Dalam teori ini, pemimpin dan pengikut mempunyai tujuan bersama yang melukiskan nilai-nilai, motivasi, keinginan, kebutuhan, aspirasi dan harapan. Dalam penyelesaian permasalahan, pemimpin informal di Desa Margodadi Kecamatan Seyegan Kabupaten Sleman Daerah Istimewa Yogyakarta menggunakan gaya kepemimpinan coaching. Menurut Shaun (2000: 92), gaya kepemimpinan coaching yaitu:

"Perilaku yang pengarahannya tinggi/dukungan tinggi. Pemimpin masih memberikan banyak pengarahan tetapi juga berusaha mendengar perasaan-perasaan pengikut mengenai keputusan, juga ide-ide dan saran dari mereka. Kontrol terhadap pengambilan keputusan tetap pada pemimpin."

Cara pemimpin informal di Desa Margodadi Kecamatan Seyegan Kabupaten Sleman Daerah Istimewa Yogyakarta dalam menyelesaikan permasalahan yaitu mengadakan pertemuan dan mengecek ke lapangan. Melalui pertemuan, pemimpin informal dan petani mendiskusikan permasalahan dengan menampung pendapat, mengecek ke lapangan, mencari penyebab dan mencari solusi. Dalam menyelesaikan permasalahan pemimpin informal memberikan penjelasan secara rinci dan mencari solusi yang mampu menyelesaikan permasalahan dengan melakukan perubahan atau terobosan baru untuk kemajuan dan kesejahteraan petani.

\section{SIMPULAN DAN SARAN}

\section{Simpulan}

Berdasarkan hasil penelitian dan pembahasan, dapat disimpulkan bahwa kepemimpinan informal dalam memberdayakan Gabungan Kelompok Tani (GAPOKTAN) di Desa Margodadi Kecamatan Sayegan Kabupaten Sleman Daerah Istimewa Yogyakarta sebagai berikut:

1. Peran kepemimpinan informal dalam memberdayakan Gabungan Kelompok Tani (GAPOKTAN) meliputi koordinator, fasilitator, pengawas, konsultan, informan, partisipan dan evaluator. Keterlibatan pemimpin informal dalam program yang dilaksanakan Gabungan Kelompok Tani (GAPOKTAN) meliputi mina padi dan pertemuan rutin. Kegiatan dalam program mina padi meliputi penyediaan pupuk, penyediaan benih ikan, penyediaan pakan, penyuluhan, pemasaran, dan ronda sawah. Selain itu, pemimpin informal terlibat dalam kegiatan pelatihan dan simpan pinjam. Peran pemimpin informal yaitu untuk mensejahterakan dan memajukan petani serta meningkatkan minat generasi muda di Desa Margodadi Kecamatan Seyegan Kabupaten 


\section{Diklus: Jurnal Pendidikan Luar Sekolah, 2(1), Maret 2018 - 34 \\ Fitri Ekasari}

Sleman Daerah Istimewa Yogyakarta.Proses kepemimpinan informal dalam memberdayakan Gabungan Kelompok Tani (GAPOKTAN) meliputi pendekatan pemimpin informal melalui pertemuan rutin, terjun langsung ke lapangan dan regenerasi dengan gaya kepemimpinan demokratis. Gaya kepemimpinan demokratis dalam penyampaian ide atau gagasan pemimpin informal bersifat terbuka yaitu mengutamakan musyawarah dan kepentingan bersama.

2. Proses kepemimpinan informal dalam memberdayakan Gabungan Kelompok Tani (GAPOKTAN) bersifat terbuka yaitu mengutamakan musyawarah dan kepentingan bersama melalui pertemuan rutin, terjun langsung ke lapangan dan regenerasi dengan gaya kepemimpinan demokratis.

3. Kendala yang dihadapi kepemimpinan informal dalam memberdayakan gapoktan yaitu faktor usia petani yang sudah lanjut, pola pikir petani yang sulit berubah membuat petani kurang mampu menerima perubahan yang diberikan pemimpin informal sehingga membuat perbedaaan pandangan, persepsi yang berbeda, dan tujuan yang tidak dicapai. Perbedaan harga antara harga petani dengan harga dipasar, panjangnya rantai distribusi dan kurangnya minat generasi muda dalam kelompok menjadi kendala pemimpin informal dalam mensejahterakan dan memajukan pertanian di Desa Margodadi Kecamatan Seyegan Kabupaten Sleman Daerah Istimewa Yogyakarta. Cara pemimpin informal dalam menyelesaikan permasalahan dalam memberdayakan gapoktan di Desa Margodadi Kecamatan Seyegan Kabupaten Sleman Daerah Istimewa Yogyakarta yaitu mengadakan pertemuan rutin dan mengecek ke lapangan.

\section{Saran}

Berdasarkan penelitian tentang kepemimpinan informal dalam memberdayakan Gabungan Kelompok Tani (GAPOKTAN) di Desa Margodadi Kecamatan Seyegan Kabupaten Sleman Daerah Istimewa Yogyakarta, maka peneliti mengajukan beberapa saran sebagai berikut:

1. Pemimpin informal perlu memperluas jaringan kerjasama dengan pihak-pihak untuk melakukan pemasaran hasil pertanian. Dilihat dari hasil pertanian, petani tidak hanya menghasilkan padi, tetapi ikan.

2. Pemimpin informal perlu adanya peningkatan kerjasama dengan para generasi muda untuk memajukan pertanian.

3. Pemimpin informal senantiasa memberikan arahan dan bimbingan kepada petani yang sulit menerima inovasi dan informasi baru. Karena sebagian besar petani memiliki usia sudah tua dan pendidikan rendah.

\section{DAFTAR PUSTAKA}

Ancaman Ketahanan Pangan : Lahan Sawah Susut 200 Ha/Tahun. (25 Februari 2017). Kedaulatan Rakyat, hlm.1.

Badan ketahanan Pangan. (2017). Statistik Perkembangan Harga Pangan di Tingkat Produsen. Diakses dari http://panelhargabkp.pertanian.go.id. Pada tanggal 12 Februari 2017 Pukul 14.00 WIB.

Badan Pusat Statistik (BPS). (2016). Jumlah Penduduk Indonesia Tahun 2016. Diakses dari www.bps.go.id. Pada tanggal 16 Februari 2017 Pukul 12.00 WIB.

Covey, S.R. (2005). The 8th HABIT : Melampaui Efektivitas, Menggapai Keagungan. Jakarta: PT Gramedia Pustaka Utama. 


\section{Diklus: Jurnal Pendidikan Luar Sekolah, 2(1), Maret 2018 - 35 Fitri Ekasari}

Departemen Pertanian. (2007). Peraturan Menteri Nomor 273/Kpts/OT.160/4/2007 tentang Pedoman Penumbuhan dan Tingkat Kelompok Tani dan Gabungan Kelompok Tani (GAPOKTAN).

Fahmi, I. 2012. Manajemen: Teori, Kasus dan Solusi. Bandung: Alfabeta

Julitriarsa, D \& Suprihanto, J. 2001. Manajemen Umum. Yogyakarta: BPFE-YOGYAKARTA

Kartono, K. (2011). Pemimpin dan Kepemimpinan: Apa Kepemimpinan Abnormal Itu?. Jakarta: PT Rajagrafindo Persada.

Kementrian Pertanian. (2015). Peraturan Pertanian Republik Indonesia Nomor 19/ Permentan/HK.140/4/2015 tentang Rencana Strategi Kementrian Pertanian Tahun 20152019.

Malahayati. (2010). I'm The Boss. Yogyakarta: Jogja Bangkit Publisher.

Pujiharto. (2010). Kajian Pengembangan Gabungan Kelompok Tani (Gapoktan) sebagai Kelembagaan Pembangunan Pertanian di Pedesaan dalam jurnal AGRITECH, Vol. XII No. $1: 64-80$.

Putri, I.E.K. (2013). Efektivitas Kepemimpinan Gapoktan "Mekar Sejahtera" Dalam Peningkatan Kedinamisan Kelompok Tani Di Desa Cipelang Bogor. Skripsi : Fakultas Ekologi Manusia. Institut Pertanian Bogor.

Rivai, V. (2013). Kepemimpinan dan Perilaku Organisasi. Jakarta: PT Rajagrafindo Persada.

. (2013). Pemimpin dan Kepemimpinan dalam Organisasi. Jakarta: PT RajaGrafindo Persada.

Saebani, B.A. (2014). Kepemimpinan. Bandung: Pustaka Setia

Safaria, T. (2004). Kepemimpinan. Yogyakarta: Graha Ilmu

Shaun, T \& Jackson, T. (2000). "The Essence of Organizational Behaviour : Perilaku Organisasi". Yogyakarta : Andi.

Sugiyono. (2012). Metode Penelitian Pendidikan: Pendekatan Kuantitatif, Kualitatif dan R\&D. Bandung : Alfabeta
Sugiyono. (2012). Metode Penelitian: Kuantitatif, Kualitatif dan R\&D. Bandung : Alfabeta

Tambunan, T.S. (2015). Pemimpin dan Kepemimpinan. Yogyakarta: Graha Ilmu

Thoha, M. (2015). Kepemimpinan dalam Manajemen. Jakarta: PT Raja Grafindo.

Wirawan. (2014). Kepemimpinan : Teori, Psikologi, Perilaku Organisasi, Aplikasi dan Penelitian. Jakarta : PT Rajagrafindo Persada.

Wuradji. (2009). The Educational Leadership: Kepemimpinan Transformasional. Yogyakarta: Gama Media 